\title{
THE CLASSICAL DRAMATIC TEXT AND ITS VALUE IN CONTEMPORARY THEATRE
}

\author{
Nina Žavbi Milojević \\ nina.zavbi.milojevic@gmail.com \\ University of Ljubljana, Slovenia
}

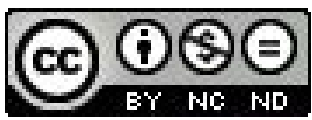

\begin{abstract}
This paper deals with the classical dramatic text and its staging in contemporary theatre. Specifically, it aims to show that classical texts can address topical issues. This is illustrated by the example of several stagings of Ivan Cankar's Hlapci, one of the most influential dramatic texts in Slovene literature. The history of this dramatic text is presented from its first publication and reception to the different stagings in various Slovene professional theatres. The focus is on how the situation in Slovene society is reflected in each examined staging. The drama Hlapci was first staged almost one hundred years ago, when the staging followed closely the dramatic text. However, after 1980 stagings became more independent from the text and more artistic freedom was allowed. The paper will prove that classical dramatic texts are very appropriate for staging in contemporary theatre, especially with an innovative director's approach.
\end{abstract}

Key words: classical dramatic text, staging, contemporary theatre, Hlapci, Ivan Cankar

\section{INTRODUCTION}

Theatre, as well as other art forms, is always a reflection of time and of a social, political and cultural situation. The presence of classical dramatic texts in the repertoires of many theatres shows that they can address topical issues and are interesting for staging. The 2012/2013 season in the Slovene National Theatre Drama Ljubljana, for example, features an interesting combination of completely modern texts and classical dramatic texts, such as The Tragedy of Hamlet, Prince of Denmark by William Shakespeare, The Mother by Bertolt Brecht or Three Sisters by Anton Pavlovich Chekhov. Sometimes stagings (not just in experimental theatres) are not only based on dramatic texts but are also adaptations of films, parts of different literary and non-literary texts. Therefore, I find it especially interesting to ask the question about the value of classical dramatic texts for contemporary theatre. My discussion focuses specifically on the drama Hlapci (Servants), written by Ivan Cankar. This choice is determined by the fact that I. Cankar is one of the most influential and prolific authors in Slovenia. So far, his plays have been staged about 30 times in different professional and amateur theatres.

This paper presents the history of Hlapci, from its publication and its first reception to the different performances in various Slovene professional theatres. The focus is on how the situation in Slovene society is reflected in each performance. The drama Hlapci was first staged almost one hundred years ago, when the tendency in theatre was to follow the dramatic text very closely. More recent theatrical renditions, however, are very different from the original dramatic text and focus 
more on topical issues. I will deal with performances that show the value of classical dramatic texts for contemporary theatre, In conclusion, I will prove that classical dramatic texts are very appropriate for staging in contemporary theatre, especially if the director adopts an innovative approach.

\section{HLAPCI AND ITS MEANING IN DIFFERENT HISTORICAL PERIODS}

Literary works written by I. Cankar have often provoked a heated debate since their first publication. They have also been frequently reviewed and have attracted much critical attention. I. Cankar's dramas are often considered controversial. Moreover, at the time they were written they were even politically controversial, which was one of the reasons why they were not so willingly published and staged. Later on, his plays grew in stature, and when political themes were no longer an issue, a whole spectrum of staging possibilities opened up. The first part of Hlapci2 is a satirical drama which criticises the Slovene intelligentsia for their lack of character. Then, in the second part, the play turns into a drama of an individual. Satirical actions turn into an intimate drama with tragic moments and a serious ending. The story is set in the time after elections ${ }^{25}$, which were won by a clerical option, despite contrary expectations. Teachers as a profession change their political affiliations over night. „The honour of a teacher demands you be white today and black tomorrow just as the master says" 26 (Cankar, 1969, p. 32). The only exception is Jerman, a teacher who, together with Kalander, a blacksmith and representative of the working class, tries to educate people. Jerman's opposite is the Minister. He wants Jerman to show him respect and recognize his authority after his political option has won the elections. The Minister is not interested in the teacher's beliefs: „Convictions, beliefs - I do not ask you for them. Since there is one word alive and understandable to all - authority" (Cankar, 1969, p. 43). Jerman does not want to recognize his authority. However, in his endeavour to be faithful to his principles, he encounters a number of obstacles connected with his personal struggle. Namely, his mother is dying and she wishes her son to give up his political activity. Jerman's mother, as a supporting character, remains in the background throughout the play. Nevertheless, she is the driving force of Jerman's inner struggle. His struggle reaches boiling point at one of the political rallies when Jerman describes those who do not want to understand him and do not want to sing a different tune as servants: „Servants! Born to be servants, raised to be servants, made to serve! Your master changes but the whip remains and shall remain forever since the back is bent, used to the whip and desiring it!" (Cankar, 1969, pp. 54, 55). Importantly, the idea of being servants by extension applies also to the Slovene nation in general. In the end, Jerman stops fighting for his cause, realizing that he is not strong enough, and cannot come out of it victorious. His fight is continued by the blacksmith Kalander. The tragedy lies in the fact that Jerman is not willing to give up either his beliefs or his hope for a better future, but he is no longer an active participant in society.

24 The drama was first published in Ljubljana in 1910 and first staged in Trieste in 1919.

25 The Slovene People's Party won at the state assembly elections in 1907.

26 All quotes that are originally in the Slovene language were translated into English by Andreja Miklavčič. 
As I will attempt to demonstrate, each historical period brought about a different understanding of this text, which can be interpreted in many different ways. The text as such always exists within a certain social context. Naturally, upon its publication, the drama itself was read differently from the way it is read today. Moreover, staging a drama produces a new work of art with its own characteristics and principles. It offers more verbal interpretation and acting, costumes, scenes, director's concept, music and etc. We can thus expect that stage renditions of any drama vary. What also changes through history is the manner in which performances were dealt with in different theatres, as well as the competences of directors and actors. The quality of all of these aspects has been improving since the beginnings of theatre in Slovenia. That is why the performances themselves vary considerably from one another and are not so contingent on the quality of the dramatic text (Žavbi Milojević, 2012, p. 373).

The drama was first staged posthumously in Trieste in 1919, not in Ljubljana. „The response to the drama revolved almost exclusively around political views" (Pogačnik, 1997, p. 263). The critics have mostly addressed questions of ideology, of whether I. Cankar painted a realistic picture of the situation in Slovenia at that time or not. At the same time, they paid less attention to the artistic value of this literary work. "They considered Hlapci only as an expression of a modern socio-political and historical moment and, to substantiate their arguments, they searched for those components of the play that confirmed their point of view" (Pogačnik, 1997, p. 263). They did not even touch on Jerman's inner struggle in their reviews. Because of its controversial political themes, staging of the drama was banned. As I have already mentioned, the drama was first staged after World War I in Trieste (directed by Milan Skrbinšek). The second staging was in Zagreb, Croatia; the third one - finally in Ljubljana. The first performances were quite stereotypical and conventional. There was nothing scandalous about them. Controversial interpretations of the play did not appear till later.

In the part that follows I will show how the understanding of this classical dramatic text has changed over time and, by doing so, I will confirm my hypothesis that classical dramatic texts can address topical issues. I will discuss in greater detail stage performances of I. Cankar's Hlapci after 1967, that is, when stagings were no longer considered to be subordinate to dramatic texts. Directors used dramatic texts more as a starting point, a source from which they could borrow what they needed and express their own opinions and views of the world. One may observe that since 1967, stagings have explicitly shown the value of Hlapci for contemporary theatre and the present time.

But let us start with a staging from 1934, directed by Ciril Debevec in SNT Drama Ljubljana. "»Hlapci« put up a most faithful mirror to us. [...] It is not limited to our homeland, our people or our historical period, not in time, nor in space. The message of Hlapci is universal"27 (Debevec, 1934/35, pp. 26, 27). The director does not view the text merely as a political satire. For instance, he sees Jerman as an idealist destined to experience disappointment in love, in every human being. As soon as Jerman comes to realize that he harmed his mother, nothing else seems to count. C. Debevec aims to "present on stage as well and as clearly as he possibly can a picture of the literary work

27 This is the fundamental difference between this performance and all the previous performances that were dealing with Hlapci mostly in the light of that specific socio-political context. 
that he carries in his mind and feelings" (Debevec, 1934/35, p. 29). As a director, he chose to remove from his spectacle the fight between the clericals and liberals on the grounds that Hlapci is a general drama of all men. Nevertheless, the performance is still to a great degree faithful to the text, but it is oriented more towards Jerman's personal drama, with some general messages. It does not focus on a specific moment in history nor the struggle between the liberals and the clerics. C. Debevec followed I. Cankar and created a universally accepted performance praised for its good acting achievements. C. Debevec's stage performance was widely recognized as the best performance up to that time. Later, the emphasis in subsequent interpretations shifted towards Jerman's personal issues. If previous stagings dealt with Jerman's social and political activities, then later renditions focused more on the protagonist's inner struggle. Jerman is a sensitive individual torn between doing what he strongly believes in (that is, being politically active) and doing what his dying mother wishes him to do.

The stagings that followed offered various readings of I. Cankar's dramatic text. In season 1948/49, the drama was directed by Slavko Jan in SNT Drama Ljubljana ${ }^{28}$. He saw Hlapci as a political drama and he wished to emphasise Kalander's continuation of the fight. He tried to do this through "realistic means of staging" (Jan, 1948, p. 54). Here realism is of course meant not in the narrow sense of an art period, but in the sense of "an artist's longing to mimic real life as well as possible" (Šega, 1949, p. 4). The novelty in this performance was the stress put on the fact that Jerman's fight was not in vain, that Kalander took over his predecessor's "heritage of ideas and struggle" (Kreft, 1948, p. 60). Therefore, the conclusion is optimistic and not related to Jerman's personal breakdown. This realistic view is summed up in the motto that prefaces I. Cankar's dramatic text: "It is the artist, whose end both at the first, and now, was and is, to hold as 'twere the mirror up to nature, to show virtue her own feature, scorn her own image, and the very age and body of the time his form and pressure..." (Hamlet). With this quotation from Shakespeare, which I. Cankar altered for his purposes, he wanted to express the objective of an artist as seen in realism. I. Cankar himself was not apolitical, so it is no surprise that he concludes his drama in a political fashion.

If we compare the staging by C. Debevec from 1934 with the one by S. Jan from 1948, we can notice that the two stagings differ a lot in their thematic emphases. Although both directors followed the dramatic text, they approached it from different angles. C. Debevec focused on Jerman's personal issues, whereas S. Jan looked at Hlapci as a political drama. Until then stagings of Hlapci resembled one another, but this tendency changed especially after 1967. At that time, the activity of Slovene theatre was in full swing, performances were considered an independent art form, freed from the constraints of literary or dramatic texts. What also allowed for innovative stagings at the time was the fact that the drama was already much divorced from its original political context.

One of such performances was staged in 1967 in the Celje People's Theatre. It was directed by Mile Korun ${ }^{29}$. M. Korun brings Jerman's psychology to the forefront. In his interpretation. Jerman is not a real hero but just pretends to be one. He is complicated and that is why there is no room for him in the world: „Both Cankar and Korun

28 This staging was a sort of turning point: for many years, it was regarded by critics as an exemplary staging.

29 M. Korun is known for his profound knowledge of I. Cankar. He has directed Hlapci four times and each staging was completely fresh and marked by the director's distinct approach. 
try to convey a certain identical, extremely critical view of the world" (Poštrak, 1991, p. 24). M. Korun opposed a realist point of view in theatre at that time. In the 60 s and 70s, however, he returned to this mode of expression. Through I. Cankar's work, he wished to address topical issues of his time. His Hlapci is built around "the hero's individual, if not already existential problem" (Poštrak, 1991, p. 29). The 1948 interpretation by $\mathrm{S}$. Jan positions Jerman in a certain period. So, Jerman is no longer a hero, he is a weak person, torn between the social and the personal. The main dilemma in the play no longer concerns a nation, but an individual. The Minister and Jerman are equal opponents. "The Minister represents a completely open, flexible, understanding and rational type of authority. He is considered smart, useful and functional" (Inkret, 1972, p. 146). Jerman's relinquishment of his political activity is seen as a failure and not a happy ending. M. Korun's staging moved away from showing a specific social and political situation and moved towards the main character's intimate world.

In season 1980/81, there were two performances of Hlapci in professional theatres in Ljubljana taking place at the same time: one by Dušan Jovanović and the other by M. Korun. Both gained increasing currency among critics, the audience and within society. "They both moved away from the original Cankar's text not only in terms of their approach to directing but with cuts into the drama's inner structure" (Kos, 1981, p. 113). "Attention was redirected to the individual" (Vurnik, 1980, p. 4).

D. Jovanović directed Hlapci in the Ljubljana City Theatre. The whole creative team tried to read the drama anew, which proved to be very difficult because of a multitude of previous interpretations and the omnipresence of the text. In D. Jovanović's rendition, parts of I. Cankar's text were omitted. It was complemented with other texts that were either borrowed from I. Cankar's other works, like his speech Kako sem postal socialist (How I became a socialist), or taken from songs and material used in schools at the time the drama was written. "The director wanted to set the staging in that specific time, which he achieved by incorporating authentic materials into Cankar's text" (Žavbi Milojević, 2012, p. 378). They wished to show a real connection with Jerman's profession. Furthermore, this was the first performance that made it clear that the main character is a teacher. There is even a choir of children influenced by frustrated and servile teachers. The performance ends with Jerman's complete breakdown and death: he shoots himself in the stomach and does not ask for a blessing. We thus witness his individual drama. Jerman is portrayed as neurotic and that is why he breaks down in the end. Then, terror starts to rule over everything, especially children. Only one child, who stands by Jerman's dead body, gives us a sense of optimism when he repeats Mi gremo naprej (We go forward), a line by the Slovene poet Oton Župančič.

The second staging in season 1980/81 in the SNT Drama Ljubljana was completely different. It was directed by $\mathrm{M}$. Korun for a second time. The staging agreed with I. Cankar's text, but, at the same time, the director's approach brought something new and fresh. The characters are treated as individuals, not as mere types. The director caricatures the characters. The atmosphere is stuffy: the characters are surrounded by a crowd. In contrast, Jerman comes onstage alone: from the very outset, he is devoid of heroism and feels insecure. As the clerics win, the Minister comes in sight and the conflict trinity is complete: servants, Jerman, authority. "Jer- 
man is leaning on Kalander" (Mermolja, 1980, p. 4), who, as a representative of the working class, can express things more clearly than the intellectual Jerman. Jerman's journey ends with his breakdown and without any hope for a new life. In the end, he is admitted to a mental institution, where they put him in a straitjacket. "As if illusions and memories are all there; that is how we can understand a group of religious women wearing black that attack the sleeping and helpless Jerman and smother him" (Videti, 1980, p. 12).

The last three mentioned performances demonstrate that a classical dramatic text can be staged in various ways. The text under review is always interesting and can be applied to different social situations. Even at the end of the previous millennium it illuminated issues that were interesting to the creators as well as the audience.

There were two more stagings on Slovene professional stages in the new millennium and they both confirm my hypothesis. One of them was directed by Samo M. Strelec in the Slovene National Theatre Maribor. The performance was entitled Hlapci.pdf. The creators wrote: "This performance of Hlapci will be something new from the very beginning, a walk on the edge, combining small pieces into a challenging whole that should move the viewer - the individual" (Gruden, 2005, p. 7). It was a modernised version of Hlapci, an innovative interpretation. The director put a completely modern twist on a classical dramatic text and directed his interest towards the contemporary individual. The costumes were modern and so was the action, which was set in the present time. Also, some real persons from the Slovene and European political and cultural scene were included in the performance. The stage itself was empty, the lights in the theatre were all lit throughout the performance and the audience was allowed to freely join in the performance.

Jerman started the performance sitting on a drummer's stool and he played the drums. This is followed by a scene with Anka, acted by a man who speaks as a woman (using the female gender). "Jerman's personal story is introduced by a video projection of an old Mercedes with a caravan driving from the countryside to the city" (Pezdir, 2005, p. 10). Notwithstanding its being a classical dramatic text, more recent stagings of the play often feature modern technology. The ending is optimistic, since Lojzka and Jerman leave together.

In season 2009/10, director Matjaž Berger staged Hlapci in co-production with the Anton Podbevšek Theatre and the Prešeren Theatre Kranj. This was "a staging accompanied by comments that Berger felt affinity with philosophers such as Pascal, de la Boétie, Hegel, Althusser" (Lukan, 2010, p. 19). During the performance, the audience could read quotes from these philosophers on a screen and these quotes illustrated the basic idea of the drama. By doing it, the director additionally showed the value of this classical dramatic text and its universality: it remains actual, regardless of time in history and any social reality. "At the same time, Cankar's text is acted out almost in its entirety, albeit the original text and Berger's rendition stress some things differently" (R. B., 2010, p. 15). The staging tackles the following topics: implanted habits, the school system, the state, children's attitude towards learning and ideology" (R. B., 2010, p. 15). Just like S. M. Strelec's stage performance, this version of Hlapci also included modern technology - a video projection. In M. 
Berger's artistic vision. the scene becomes a track, covered by sand divided from the stage by a transparent projection screen. "In the background, there are three boxes raised from the ground that can be climbed onto by ladders which have long knives instead of rungs" (Lukan, 2010, p. 19). Such an arrangement is meant to illustrate that truth hurts. This is a modern performance that discusses many topical issues in today's society.

\section{CONCLUSION}

In conclusion, it is essential to return to my original question of whether a classical dramatic text is appropriate and valuable for staging in contemporary theatre. I believe that on the basis of the analysis of Hlapci, a classical dramatic text by I. Cankar, this question may be answered in the affirmative. Through the examination of the published drama and its different stage performances within the span of 100 years, I have proved that Hlapci is a text that can function in various historical, social and political contexts. Upon its publication, it served as an illustration of the specific socio-political circumstances of that time and that is why it received a variety of reviews and responses. After some time, the text started functioning on other levels. The universal questions it deals with came to the forefront. It tackles political subjects and addresses the question of the crowd, the question of changing principles or lack of principles, the question of serving and authority, the question of a son's love for his mother, the question of an inner conflict, the question of being torn between love and political beliefs. Every director, every performance dealt with the text from a different perspective. Moreover, they focused on different themes in different historical periods. Especially after 1967 performance was recognized as an independent form of art that did not acknowledge supremacy of dramatic texts and was allowed to move away from it and even change it in part. Therefore, performances grew increasingly different and innovative. I. Cankar's dramatic texts are often seen in Slovene professional theatres even in the new millennium. In this paper, I mentioned two distinctly modern performances and I included other stagings that I believe best substantiate my thesis. I focused only on one dramatic text by I. Cankar - Hlapci. However, there have been also other I. Cankar's dramas staged in recent years, including Pohujšanje $v$ dolini šentflorjanski (Scandal in the St Florian Valley) that was put on stage by director Vito Taufer in 2012 in the Mladinsko Theatre.

Before I conclude, I would like to mention something interesting. Different quotes from I. Cankar's Hlapci are commonly used in Slovenia in everyday discourse and when people fight for their rights. For example, in May 2012 students of the Academy of Theatre, Radio, Film and Television read this drama in front of Slovene parliament as a sign of protest against austerity measures. In my opinion, this again proves that I. Cankar's text can address topical social and political issues as it could also one hundred years ago. And therein lies its true value. 


\section{REFERENCES}

\section{Sources}

Cankar, I. (1969). Hlapci, Zbrano delo 5 [The Servants, Collected Work 5]. Ljubljana: Državna založba Slovenije.

\section{Bibliography}

Debevec, C. (1934/35). Razgovor o "Hlapcih" [Conversation about The Servants]. Gledališki list SNG Drama Ljubljana [Theatre Journal of SNG Drama Ljubljana], 4, 26-29.

Gruden, G. L. (2005). Hlapci.pdf. Jerman proti Jermanu [The Servants.pdf. Jerman versus Jerman]. Maribor: Drama SNG.

Inkret, A. (1972), Ivan Cankar, Hlapci [Ivan Cankar, The Servants]. In: Gledališki feljtoni [Theatre's Feuilletons] (pp. 138-146). Ljubljana: Cankarjeva založba.

Jan, S. (1948/49). Hlapci [The Servants]. Gledališki list SNG Drama Ljubljana [Theatre Journal of SNG Drama Ljubljana], 3, 50-57.

Kermauer, T. (1979). Cankarjeva dramatika [Drama of Ivan Cankar]. Ljubljana: Samozaložba.

Korun, M. (1997). Režiser in Cankar [Director and Cankar]. Ljubljana: Mestno gledališče ljubljansko.

Kos, J. (1981). Ljubljanska dramaturgija, Hlapci 1980 [Ljubljana Dramaturgy, The Servants 1980]. Sodobnost [Modernity], 29/2, 113-128.

Kozak, P. (1980). Temeljni konflikti Cankarjevih dram [The Main Conflicts of Cankar's Drama]. Ljubljana: Cankarjeva založba.

Lukan, B. (2010). Hlapci s komentarji [The Servants with Comments]. Delo [Work], 17.3.2010, 19.

Mermolja, A. (1980). Izvirno branje Cankarjevega teksta in igra vrhunske umetniške vrednosti [Original Reading of Cankar's Text and Top Artistic Value Acting]. Primorski dnevnik [Primorski Journal], 15.3.1980, 9 (and 18.3.1980, 4).

Pezdir, S. (2005). Hlapci na svoji zemlji [The Servants on Their Own Land]. Delo [Work], 17.5.2005, 10.

Pirjevec, D. (1968). Hlapci, heroji, ljudje [Servants, Heroes, People]. Ljubljana: Cankarjeva založba.

Pogačnik, J. (1997). Prispevek k pojmu literarne identitete (Cankarjevi Hlapci v slovenski in hrvaški kritiki) [Contribution to the Concept of Literary Identity (The Servants by Ivan Cankar in Slovenian and Croatian Criticism)]. Traditiones: Zbornik Inštituta za slovensko narodopisje in glasbenopisje [Traditions: Journal of Institut for Slovenian Ethnology and Musicology], 26, 257-269.

Poštrak, M. (1991). Konfrontacija s Cankarjem [Confrontation with Cankar]. Maske: revija za gledališče [Masks: Journal for Theatre], 18, 24-31.

R. B. (2010). V ATP o hlapcih 21. stoletja [In ATP about Servant of the 21. Century]. Dolenjski list [Dolenjski Paper], 11.3.2010, 15.

Šega, D. (1949). Pot v realizem (ob uprizoritvi Cankarjevih »Hlapcev« v ljubljanski Drami) [Way to Realism (Staging of The Servants by Ivan Cankar in SNG Drama Ljubljana)]. Ljudska pravica [People's Right], 13.1.1949, 4.

Videti (tudi) Korunovo različico Cankarjevih HLAPCEV v ljubljanski Drami in jo primerjati z Jovanovićevo v Mestnem gledališču [To (also) See Korun's Version of Cankar's The Servants in SNG Drama Ljubljana and to Compare It with Jovanović's in City Theatre]. Teleks [Teleks], 24.10.1980, 12-13.

Vurnik, F. (1980). Dušenje Jermana [Suffocation of Jerman]. Dnevnik [Journal], 20.10.1980, 4.

Žavbi Milojević, N. (2012). Uprizoritve Hlapcev Ivana Cankarja od začetkov do danes [Stagings of The Servants by Ivan Cankar from Beginnins to Today]. In: M. Pezdirc Bartol (ed.), Slovenska dramatika [Slovenian Drama] (pp. 373-380). Ljubljana: Znanstvena založba Filozofske fakultete. 